\title{
THE DNA CONTENT OF SPERMATOZOA FROM DIFFERENT STRAINS OF MICE
}

\author{
G. P. M. MOORE* AND R. A. BEATTY $\dagger$ \\ Department of Genetics, University of Edinburgh, \\ West Mains Road, Edinburgh 9, Scotland
}

(Received 14th November 1973)

Certain morphological characters of mammalian spermatozoa have been shown to have a high heritability (Beatty, 1970). Sperm dimensions may be altered by genetic selection (Woolley, 1970). In addition to the biological action of the genes, the actual mass of the DNA and proteins, which constitute the major components of the head, may affect the sperm phenotype. Unlike genetically active cells in which nuclear size is governed, to a certain extent, by metabolic factors, the sperm genome is condensed, homogeneous and inactive. It might therefore be expected that head size would be influenced both by the quantity of DNA present and by the way it is condensed. Thus diploid spermatozoa have enlarged heads (Beatty \& Fechheimer, 1972), whereas spermatozoa with abnormally small heads might have a lower Feulgen-DNA content than morphologically normal members of the same ejaculate (Gledhill, 1970). The size differences described in the latter studies probably reflect alterations in sperm chromatin structure affecting the availability of Feulgen-reactive sites. When the DNA contents of small and normal spermatozoa were compared by ultraviolet (u.v.) absorption methods, no significant differences were observed (Gledhill, 1970). There are also many instances in the literature of variations in Feulgenand u.v.-DNA contents in morphologically normal spermatozoa of fertile and subfertile animals (Leuchtenberger, Leuchtenberger, Schrader \& Weir, 1956; Leidl \& Stolla, 1969; Gledhill, 1970), although no actual measurements of sperm head dimensions were recorded in some of these studies. Expected variations in the DNA content, as in X-and Y-bearing spermatozoa can be detected chemically but not morphologically (Beatty, 1970; Evans, 1972).

In an attempt to clarify the relationship between genome and head size, Feulgen-DNA measurements were made in strains of mice in which variations in morphology have been reported (Beatty \& Sharma, 1960). Four inbred strains were studied: A, JBT, CBA and C57. The spermatozoa of these strains are known to differ from each other in the size and shape of the head and midpiece. If head area alone is considered, A $>$ CBA $>$ JBT $>$ C57, but the only significant differences are those involving C57 (see Table 1).

Two males from each strain, aged between 9 and 11 weeks, were used. Spermatozoa from the ductus deferens were dispersed in a small volume of saline and smeared on glass slides. Each slide (A series) bore a total of eight

* Present address: The Department of Zoology, Australian National University, Canberra, A.C.T., Australia.

† Agricultural Research Council Unit of Animal Genetics. 
smears, one from each male, in the randomized order in which the mice were killed. A duplicate set of slides was also prepared in which the order of smears was reversed (B series). When dry, the smears were fixed in methanol/formalin/ acetic acid (85/10/5 by vol.) for 90 min (Böhm, Sprenger, Schlüter \& Sandritter, 1968), washed in distilled water and hydrolysed in $5 \mathrm{~N}-\mathrm{HCl}$ at $23^{\circ} \mathrm{C}$. A time curve for the hydrolysis of DNA was obtained by removing slides from the acid bath at successive 5- or 10-min intervals and washing them thoroughly in running water. The Feulgen reaction was performed in freshly prepared Schiff reagent at $\mathrm{pH} 1.5$ for $60 \mathrm{~min}$. Quantitative measurements of the Feulgen reaction were made on a Barr \& Stroud integrating micro-densitometer at a wavelength of $560 \mathrm{~nm}$. The slides were arranged in a randomized order and ten spermatozoa from each smear were measured. The absorption of each cell was recorded in arbitrary units.

Table 1. Comparisons of group averages of sperm characteristics of mice of different inbred strains

\begin{tabular}{|c|c|c|c|c|c|}
\hline \multirow{2}{*}{ Strain } & \multirow{2}{*}{$\begin{array}{c}\text { Feulgen-DNA } \\
\text { maximum absorption }\end{array}$} & \multirow{2}{*}{$\begin{array}{l}\text { Hydrolysis } \\
\text { time (min) at } \\
\text { maximum } \\
\text { absorption }\end{array}$} & \multirow{2}{*}{$\begin{array}{l}\text { Nuclear area } \\
\left(\mu m^{2}\right)\end{array}$} & \multicolumn{2}{|c|}{ Head area $\left(\mu m^{2}\right)$} \\
\hline & & & & $A$ & $B$ \\
\hline $\begin{array}{l}\text { JBT } \\
\text { A } \\
\text { C557 } \\
\text { CBA }\end{array}$ & $\begin{array}{l}11.5 \\
11.0 \\
10.9 \\
10.5\end{array}$ & $\begin{array}{l}57 \cdot 6 \\
53 \cdot 7 \\
56 \cdot 5 \\
55 \cdot 0\end{array}$ & $\begin{array}{l}14 \cdot 01 \\
15 \cdot 40 \\
12 \cdot 81 \\
14 \cdot 26\end{array}$ & $\begin{array}{l}2 \overline{-} \cdot \overline{5} \\
22 \cdot 4 \\
24 \cdot 3\end{array}$ & $\begin{array}{l}23.9 \\
24 \cdot 3 \\
=\end{array}$ \\
\hline $\begin{array}{l}\text { S.E. per strain } \\
\text { mean }\end{array}$ & $\begin{array}{l} \pm 0 \cdot 123 \\
(4 \text { d.f. })\end{array}$ & $\begin{array}{l} \pm 0.93 \\
(4 \text { d.f. })\end{array}$ & $\begin{array}{l} \pm 0.33 \\
(4 \text { d.f. })\end{array}$ & $\begin{array}{l} \pm 0 \cdot 166 \\
(96 \text { d.f. })\end{array}$ & $\begin{array}{l} \pm 0 \cdot 243 \\
(8 \text { d.f. })\end{array}$ \\
\hline $\begin{array}{l}\text { Overall } \\
\text { significance of } \\
\text { strain mean } \\
\text { differences }\end{array}$ & $0.025>P>0.01$ & $P>0.05$ & $0.025>P>0.0 \mathrm{I}$ & $P<0.005$ & $0.4>P>0.2$ \\
\hline
\end{tabular}

A - data from Beatty \& Sharma (1960); B - data from unpublished observations by R. A. Beatty and P. S. Burgoyne.

The error terms for testing overall strain differences were the males-within-strains mean squares in. analyses of variance. The S.E. per strain mean was derived from the same mean squares.

From the absorption measurements, sixteen hydrolysis curves were plotted, one for each smear from the A and B series of slides. The regression of absorption on time was computed for each curve by means of a third degree polynomial regression, accounting for about $97 \%$ of the variance. From each curve, the maximum absorption and the hydrolysis time at maximum absorption were calculated. Analyses of variance of the sixteen maxima and hydrolysis times indicated that maximum absorption was consistent between males of the same strain but significant differences existed between strain means. The hydrolysis times at which maximum absorption was obtained did not differ significantly between males within strains or between strain means. Strain means of the maximum absorption points on the hydrolysis curves are presented in Table 1. Of the four strains, JBT showed the highest absorption and CBA the lowest. Spermatozoa from A and C57 strains lay between these but did not differ 
significantly from each other. The DNA hydrolysis curves from pooled data of the two most contrasted strains differed from each other at every time point.

These results clearly do not support a correlation between head size and Feulgen-DNA content when the values are compared with measurements of head area obtained from previous studies (Table 1). This conclusion may also be drawn from the work of Döring, Gropp \& Tettenborn (1972) who demonstrated that the aneuploid spermatozoa of Fl hybrids of NMRl strain mice and $M$. poschiavinus (the tobacco mouse) have smaller heads than either of the euploid parental strains but that Feulgen-DNA contents were intermediate in value. Furthermore, Godowicz \& Krzanowska (1966) showed that spermatozoa from the inbred mouse strains, $\mathrm{KP}$ and $\mathrm{KE}$, differed from those of an outbred strain in head area but not in Feulgen-DNA content.

A possible relationship between DNA content and the size of the sperm nucleus alone was also investigated. The nuclear areas were measured in Feulgen-stained smears which had been hydrolysed for $60 \mathrm{~min}$. Ten spermatozoa from each smear were measured in optical projection by the methods of Beatty \& Sharma (1960). An analysis of variance of the measurements indicated that the males-within-strains variation was not significant, but strain means differed significantly from each other (Table 1). Again, there was no correlation between nuclear area and Feulgen-DNA content. The spermatozoa which were most different in DNA content (JBT, CBA) had similar nuclear areas, whereas those with similar DNA contents (A, C57) were the most unlike in area.

The strain differences in sperm Feulgen measurements require explanation. It has been shown that the Feulgen-DNA contents of ejaculated spermatozoa are lower than those of epididymal or testicular spermatozoa (Bouters, Esnault, Salisbury \& Ortavant, 1967). In the present study, all the spermatozoa were taken from the same region of the genital tract and were processed for the Feulgen reaction by methods prescribed to eliminate proportionality errors (Böhm et al., 1968). If the mode of chromatin condensation within the sperm head differs between strains, it is not related to nuclear size. It also seems unlikely that strain variations in the rates of passage of spermatozoa into the ductus deferens influence their Feulgen reactivity as a result of differential ageing (Gledhill, 1970) since spermatozoa of different ages are mixed in the epididymis (Orgebin-Crist, 1965). The measurements may, however, represent actual differences in the type or quantity of DNA. A source of such variation may lie in that portion of the genome composed of sequences which occur with varying degrees of repetition. A recent survey of a number of rodent species has shown that between 10 and $20 \%$ of the genome may be composed of repeated sequences. This DNA class includes a highly reiterated fraction called satellite DNA which forms a variable constituent of the genome (Hennig \& Walker, 1970). These differences refer only to the proportion of repeating sequences present in the DNA and give no information about genome size. Yasmineh \& Yunis (1970) have reported that the Feulgen-DNA content of cells from rodents of the same subfamily is approximately related to the amount of constitutive heterochromatin. Such findings may provide a partial explanation for the results presented here, but it is concluded that the strain-specific differences in 
Feulgen-DNA measurements have no direct bearing on sperm phenotype.

We are obliged to Mr N. Hamilton-Smith of the Edinburgh Regional Computing Centre, to Dr R. F. Lyndon of the Botany Department, Edinburgh University, and to Mr V. Coulter and Mr P. Burgoyne for assistance. The study was supported by a Ford Foundation grant to one of us (R.A.B.) and by the Wellcome Trust.

\section{REFERENCES}

BEATTY, R. A. (1970) The genetics of the mammalian gamete. Biol. Rev. 45, 73.

Beatty, R. A. \& FechHeimer, N. S. (1972) Diploid spermatozoa in rabbit semen and their experimental separation from haploid spermatozoa. Biol. Reprod. 7, 267.

Beatty, R. A. \& Sharma, K. N. (1960) Genetics of gametes. III. Strain differences in spermatozoa from eight inbred strains of mice. Proc. R. Soc. Edinb. B, 68, 25.

Böhm, N., Sprenger, E., Schlürer, G. \& Sandritrer, W. (1968) Proportionalitätsfehler bei der Feulgen-Hydrolyse. Histochemie, 15, 194.

Bouters, R., Esnault, C., Salisbury, G. W. \& Ortavant, R. (1967) Discrepancies in analyses of DNA in rabbit spermatozoa, involving Feulgen staining (Feulgen-DNA) and ultraviolet light absorption (UV-DNA) measurements. 7. Reprod. Fert. 14, 355.

Döring, L., Gropp, A. \& TetTenborn, U. (1972) DNA content and morphological properties of presumably aneuploid spermatozoa of tobacco mouse hybrids. 7. Reprod. Fert. 30, 335.

Evans, H. J. (1972) Properties of human X and Y sperm. In Proc. Int. Symp, The Genetics of the Spermatozoon, p. 144. Eds. R. A. Beatty and S. Gluecksohn-Waelsch. Departments of Genetics of the University of Edinburgh and the Albert Einstein College of Medicine, Edinburgh and New York.

GLEDHILL, B. L. (1970) Changes in nuclear stainability associated with spermateliosis, spermatozoal maturation and male infertility. In Introduction to Quantitative Cytochemistry, II, p. 125. Eds. G. L. Weid and G. F. Bahr. Academic Press, New York.

Godowicz, B. \& KRzanowsKa, H. (1966) DNA content of mouse spermatozoa from inbred strain KE of low male fertility. Folia biol., Krakíw, 14, 235.

Hennig, W. \& Walker, P. M. B. (1970) Variations in the DNA from two rodent families (Cricetidae and Muridae). Nature, Lond. 225, 915.

Leidr, W. \& Stolla, R. (1969) Individual difference of UV-DNA in spermatozoa of boars. F. Reprod. Fert. 18, 173.

Leuchtenberger, C., Leuchtenberger, R., Schrader, F. \& Weir, R. (1956) Reduced amounts of DNA in testicular germ cells of infertile men with active spermatogenesis. Lab. Invest. 5, 422.

Orgebin-Crist, M. C. (1965) Passage of spermatozoa labelled with thymidine- ${ }^{3} \mathrm{H}$ through the ductus epididymis of the rabbit. F. Reprod. Fert. 10, 241.

WooleEY, D. M. (1970) Selection for the length of the spermatozoon midpiece in the mouse. Genet. Res. 16, 261.

YAsMineh, W. G. \& Yunis, J. J. (1970) Localization of mouse satellite DNA in constitutive heterochromatin. Expl Cell Res. 59, 69. 